\title{
DELIVERY TIMES AND DELAY IN DELIVERY OF CONSIGNMENT UNDER THE CONDITIONS OF INTERNATIONAL CARRIAGE
}

\author{
Jarmila Sosedová*, Zuzana Otáhalová, Andrej Dávid, Andrea Galieriková \\ Faculty of Operation and Economics of Transport and Communications, University of Zilina, Slovak Republic \\ *E-mail of corresponding author: jarmila.sosedova@fpedas.uniza.sk
}

\begin{abstract}
Resume
Delivery time means a certain period in which the carrier is obliged to transport the consignment from one place to another. The delay occurs when the carrier does not deliver the consignment to the consignee within this period. The authors analyse individual legislative documents regulating the transport - legal conditions of international transport. In addition, they present the reasons for the delay in delivery of the consignment and point to the carrier's liability for non-fulfilment of the obligation to transport the consignment within the delivery period. By comparing the results, authors state that there is a diversity of regulations in the field of international transport, especially in the context of the multimodality development. Such a diversity in regulations causes inconsistencies in the transport market and therefore there is a need to harmonize unimodal transport systems.
\end{abstract}

Available online: https://doi.org/10.26552/com.C.2021.4.A248-A255

\section{Article info}

Received 21 January 2021

Accepted 19 March 2021

Online 16 September 2021

\section{Keywords:}

delivery time,

carrier,

carriage of goods

\section{Introduction}

A delay in delivery of a consignment is related to a question of a delivery time. The delivery time means a certain time segment when a carrier is obliged to conduct a carriage and its related operations, i.e. to carry a consignment from one certain place (of shipment) to another certain place (of delivery, or destination). A time lag/delay happens when the carrier does not deliver the consignment to its recipient within this time segment, provided there are no obstacles to the delivery, which would release the carrier from liability for failure to meet the commitment to carry the consignment within the delivery time.

The reasons for a delay in delivery of the consignment may be both factual and legal. The factual reasons for a delay in delivery may lie in the impossibility to load or unload the consignment due to unsound technological transhipment equipment, a destruction of the consignment due to a breakdown, a theft of the consignment, a fire of a transport means, a freight explosion, etc.

The legal obstacles to a proper delivery of the consignment and a fulfilment of the contract of carriage mainly include a ban on export and import, or transit of the carried freight through a certain territory, a stoppage of carriage due to incomplete transport documentation, an infringement of provisions for the consignment carriage (mainly in the case of dangerous cargo carriage), a seizure of the freight by public authorities or an enforcement of a lien by the carrier, or another legal action of a third party towards the consignment (e.g. an execution based on a final judicial ruling towards the consignor or consignee of the consignment).

The following parts of the paper will deal with issues of a delay in delivery of a consignment and claims resulting from delay in delivery or non-observing the delivery time in individual (unimodal) transport systems [1].

\section{Delivery time in international carriage of goods}

Complaints about delays in the delivery of goods are one of the most common disputes in international transport between the consignor and the consignee. In order to be able to take adequate measures, both parties must be aware of their rights and obligations arising from the transport process [2].

The international carriage of goods by sea [3-6] is governed by various conventions such as the International Convention for the Unification of Certain Rules of Law Relating to Bills of Lading (Hague Rules) [7], Protocol to Amend the International Convention for the Unification of Certain Rules Relating to Bills of Lading 1924, (Hague - Visby Rules) 1968, 1979; [8] United Nations Convention on the Carriage of Goods by Sea, 1978 (Hamburg Rules) [9], United Nations Convention on Contracts for the International Carriage of Goods 
(Wholly or Partly) by Sea, 2008 (Rotterdam Rules) [10]. Those rules established the minimum obligations, maximum immunities and the limit of carrier's liability and aims at creating one uniform law concerning the international carriage of goods by sea. Nevertheless, none of those attempts has been successful, instead, the present legal framework consists of a disordered array of international conventions designed to regulate the carriage of goods by sea, diverse regional/sub-regional agreements, national laws and standard term contracts. As a consequence, both the applied liability rules and the degree and extent of carrier's liability vary greatly from case to case and are unpredictable. Modern transport patterns and practices have been considerably affected by the growth of containerized transportation together with technological developments on the multimodal transferring systems [11-15]. In 1996, considering the absence of an updated maritime transport regime, the United Nations Commission on International Trade Law (UNCITRAL) proposed to include a review of modern practices and applicable law regimes in the international carriage of goods by sea in its work program with a view of establishing the need for uniform rules where such rules were lacking, so as to achieve greater uniformity of laws [16]. Accordingly, it assigned to the Secretariat the task of collecting information, ideas and opinions Reviews and analysis of the rules, instructions, conventions, etc. from governments and international organizations representing commercial sectors involved in the carriage of goods by sea. Increasingly, big liner shipping companies, some of which dominate the container shipments of ocean trade, are also expanding their services to offer transportation from door-to-door by involving other carriers to perform different modal stages of a multimodal transaction [14, 17-19]. The current liability framework reflects few developments that have taken place in terms of transport patterns, technology and markets. The international uniform regime has not been in force to govern liability for loss, damage or delay arising from multimodal transport.

\subsection{Delivery time under the commercial code}

Under the Contract of Carriage of Goods, pursuant to Article 610 of the Commercial Code - Act No. 513/1991 Coll. (the Commercial Code), a carrier is committed to a consignor to carry a package (a consignment) from a certain place (of shipment) to another certain place (of destination) and the consignor is committed to pay them a remuneration (a freightage) for this service. Under Article 617, the carrier is obliged to perform the carriage to the place of destination with diligent care within the agreed time, in other words without undue delay. Thus, if the time was not negotiated it is impossible for the carrier to store the freight into a warehouse and to start the carriage with a significant delay. For such a case the Commercial Code expressly defines that, when in doubts, the time starts to pass as of the day following the day when the consignment was accepted by the carrier. The amendment of the Commercial Code in Article 624 specifies that in the case of loss or damage of the consignment, the carrier is obliged to compensate the price of the consignment valid in time it was passed to them. In the case of damage or impairment of the consignment, the carrier is required to reimburse the difference between the price, which the consignment had at the moment of its acceptance by the carrier and the price, which the damaged or impaired consignment would have had at that time. The carrier is entitled to get the negotiated remuneration, or if not-negotiated the remuneration standard in time when the contract was concluded, considering the content of the carrier's commitment. The carrier becomes entitled to the freightage after the carriage to the place of destination is performed, if the contract does not determine another time as decisive. If the carrier cannot complete the carriage, due to facts they are not liable for, they are entitled to get an aliquot amount of the freightage, taking into account the carriage already performed. The legislation, however, does not mention any sanctions or a scope of claims of the consignor in the case of a delay in delivery.

The indemnification due to delay in delivery of the consignment would apply to damages of the consignment itself, as well as to damages directly related to the breach of commitments, accruing from the contract of carriage (Article 373 et seq. of the Commercial Code on the indemnification and breach of obligations resulting from a contractual relationship). In such a case, the burden of proof would lie on a plaintiff and a defendant - carrier would be entitled to invoke all the circumstances related to waiving their liability. The indemnification would include the actual damage, as well as loss of profit.

Under Article 629 of the Commercial Code, the implementing rules may differently regulate railway, air, road, inland water and sea transport, in terms of the origin of the contract, transport documents, exclusion of a package from carriage, acceptance of the consignment by the carrier and its dispatch to the consignee, scope of claims for the carrier and their fulfilment. This regulation, however, must not reduce the liability of the carrier in the case of the consignment damage.

\subsection{Delivery time in international carriage by road under the CMR}

The CMR (Convention Marchandise Routiere) - Convention on the Contract for the International Carriage of Goods by Road [20], in its Article 19 defines the delivery time as a time negotiated by parties; if it is not negotiated, then it is the time, which can be expected from a diligent carrier. In the case of a delay in delivery of the consignment there, of course, exists a consignor's/ consignee's claim to get the indemnification occasioned 
on the consignment itself, which was established in compliance with provisions of Article 23 of the CMR. In the case of exceeding the delivery time the eligible party also has a claim to the indemnification but only up to the amount of the freightage and provided that the eligible party proves the damage due to exceeding the delivery time and makes a claim within 21 days since the consignment dispatch. If exceeding the delivery time (e.g. of engineering components carriage) does not result in any damage (e.g. due to a sufficient stock capacity of carried goods at the consignee's site) and there happens no consignment damage, the eligible party will not be allowed to claim to compensation. The indemnification may consist of direct reimbursements, e.g. as a result of a production outage and indirect ones, provided they are provable and have a causal relationship with delay in delivery of the consignment. Those claims may refer to the reimbursement of a contractual penalty for the sub-customer, subsequent paid duty, loss of profit, claim due to price decrease or loss of market value of the consignment.

The consignor may claim a higher compensation, in compliance with Article 26 of the CMR, only if they together with the carrier negotiate the so-called particular interest in delivery of the consignment in the case of exceeding the delivery time and if the consignor pays a negotiated surcharge. In such a case the eligible party may claim to the indemnification due to delay in delivery of the consignment up to the amount quoted in the consignment note. These reimbursed damages will also include a purchase of destroyed or lost goods, loss of business, taxes and charges related to the freight and carriage, etc.

If a delay in delivery of the consignment arises due to an intentional act or negligence of the carrier equivalent to the intent, there will not be applied the maximum limit for the indemnification in the amount of the freight, but the carrier will be obliged to reimburse the incurred loss to the full extent. These consequences may mean a bankruptcy for the carrier since the damages caused intentionally or in gross negligence are not covered by insurance [21].

\subsection{Delivery time in international carriage by rail under the COTIF/CIM}

The COTIF (Convention relative aux transports internation aux ferroviaires) - Convention Concerning International Carriage by Rail [22], in its Appendix CIM related to international carriage of goods by rail, in Article 16, determines the delivery times for wagon and individual packages, although it takes the agreement between the consignor and the carrier as the basis for the delivery time determination. Under Article 23 of the CIM the carrier is liable for damage caused with exceeding the delivery time and they are waived this liability if the delivery time exceeding was caused by an eligible party, by order of an eligible party, due hidden defects of goods or circumstances, which could not have been avoided and whose consequences could not have been averted by the carrier. Article 23 Paragraph 3 also quotes situations when the carrier is waived the liability (carriage in open wagons, missing or faulty wrapping, natural ability of the goods to lose its properties, etc.).

To determine the extent of indemnities, the provision of Article 33 of the CIM is decisive - if the damage happens due to exceeding the delivery time, the carrier is obliged to pay the compensation, which represents no more than the four times the freightage. If the freight is completely lost, there is no compensation up to the four times of the freightage concurrently payable with the indemnity for loss of the consignment. In the case of partial loss of the freight, the indemnity reaches maximum four times of the freightage in proportion to the lost part of the consignment. In the case of the freight damage, which is not a consequence of exceeding the delivery time the indemnity is provided in parallel with the indemnity for the consignment damage. At the same time, however, Article 33 Paragraph 5 of the CIM establishes that the indemnity for exceeding the delivery time along with the indemnity for loss or damage of the consignment must not in any case be higher than the indemnity in the case of total loss of the freight.

In this context, it is necessary to highlight that the indemnity reaches 17 units of account (SDR, XDR) per each missing kilogram of gross weight of the consignment. At the same time, the COTIF assumes that if the delivery time is set by agreement, then there in this agreement it is possible to predict a different arrangement of the indemnity in connection with delay in delivery, as well. Provided the maximum delivery time, set in Article 16 Paragraph 2 of the CIM appendix, is exceeded, then the entitled party may request the indemnity negotiated with the carrier (i.e. a higher indemnity, too).

Under Article 35 of the CIM, in the case of exceeding the negotiated delivery time the consignor may enter into agreement with the carrier regarding the so-called indemnity, with quotation of interest in delivery of the freight, provided the consignor will record the calculated amount of their interest in the consignment note. Then, if a damage is occasioned due to exceeding the negotiated delivery time, this indemnity may be asked for up to the amount stated in the consignment note.

Under Article 36 of the CIM all the limitations of the carrier's liability will not be applied in the case of proving that the damage was caused with an act or negligence of the carrier, conducted either with intent to cause such a damage or with negligence and the knowledge of the carrier that such a damage could probably have happened (deliberate negligence). 


\subsection{Delivery time in international carriage by air under the Warsaw convention and Montreal protocol}

This Convention for the Unification of Certain Rules for International Carriage by Air (1929, Warsaw Convention) [23], in its Article 19 defines that the carrier is liable for damage occasioned by delay in carriage of passengers, baggage or cargo by air. In the case of a delay, the limit of the carrier's liability is fixed at a sum of 250 francs per kilogram of the consignment's weight (for the purposes of the reimbursement calculation a franc means a monetary unit, which corresponds to 65.5 milligrams of gold of millesimal fineness nine hundred) [23].

In the case the consignor makes a special declaration of interest in delivery at destination and pays a supplementary sum at the moment when the consignment is handed over to the carrier, the carrier is obliged to indemnify the consignor the for a delay in delivery of the freight up to the amount negotiated. However, under Article 25 of the Warsaw Convention, the limit of liability mentioned above is not applicable in the case of proving that the damage resulted from an act or negligence of the carrier or their employees, done either with intent to cause such damage, or recklessly and with the knowledge that the damage would probably have resulted. At the same time, it is required to prove that the act, omission or negligence emerged or occurred within the scope of their employment. Furthermore, there is the condition that in the case of a delay in delivery of the consignment there must be a complaint against the carrier filed within 21 days from the date on which the baggage or cargo have been passed to the consignee.

The Convention for the Unification of Certain Rules for International Carriage by Air (1999, Montreal Protocol) in its Article 19 establishes the carrier's liability for damages occasioned by delay in carriage by air with the exception when the carrier proves that they and their employees and agents made all efforts and took all measures to avoid the damage or that it was impossible for them to take such measures. The liability of the carrier for a delay in delivery of the freight is limited with the sum of 19 units of account (SDR/XDR) per kilogram (under the legislation in force since 30 . 12. 2009). Like the Warsaw Convention the Montreal Protocol allows for the consignor to make a special declaration of interest in delivery at destination and pay a supplementary sum at the time the freight is handed over for the carriage. In such a case the carrier is liable for the damage occasioned and is obliged to provide the compensation up to the designed amount. The value limit of the carrier's liability is not applicable in the case of proving that the damage happened due to an act or negligence of the carrier, their employees or agents, done either with intent to cause such damage, or recklessly and with the knowledge that the damage would probably have happened. In the case of a delay in delivery of the consignment the entitled party must file a complaint within 21 days from the date on which the baggage or freight have been passed to the consignee [24].

\subsection{Delivery time by inland waterways under CMNI}

The CMNI (Convention de Budapest relative au contract de transport de merchandises en navigation interieure) [25] - the Budapest Convention on the Contract for the Carriage of Goods by Inland Waterways in its Article 16 defines the liability of the carrier for a damage occasioned due to exceeding the delivery time, unless it is shown that the damage was due to circumstances, which a diligent carrier could not have prevented and the consequences of which he could not have averted. The delivery time, as indicated in Article 5 , is the time limit agreed in the contract or, if there is no contractual agreement, it is the time limit, which could reasonably be required of a diligent carrier, taking into account the circumstances of the voyage and unhindered navigation [26].

Under Article 20 Paragraph 3 of the CMNI, the carrier's liability for the damage due to a delay in delivery shall not exceed the amount of the freightage. However, the full indemnification shall not exceed the amount, which would correspond to total loss of the freight based on the calculation done. The maximum limits of liability do not apply where the nature and higher value of the goods have been expressly specified in the transport document and the carrier has not refuted those specifications, or where the parties have expressly agreed to higher maximum limits of liability. Under Article 21 of the CMNI, the carrier loses the right for protection granted with the limited compensation, if it is proved that they themselves caused the damage by an act or negligence, either with the intent to cause such damage, or recklessly and with the knowledge that such damage would probably have resulted [26-27].

\subsection{Delivery time in carriage by sea under the Hague, Hague-Visby, Hamburg and Rotterdam rules}

Neither the Hague Rules [7] (International Convention for the Unification of Certain Rules of Law Relating to Bills of Lading), nor the Hague-Visby Rules (Protocol to Amend the International Convention for the Unification of Certain Rules of Law Relating to Bills of Lading) do directly deal with the question of the carrier's liability for a delay in delivery of the consignment. The indemnification is provided only in the case of damages of the freight itself, or damages related to the freight. Under the Hague Rules, the limited indemnities represent 100 pounds sterling per 
package or unit, or a counter-value of this amount in another currency. Under the Hague-Visby Rules the limit of the carrier's liability is restricted with an amount of 2 units of account (SDR/XDR) provided the damage was not caused with negligence of the carrier intentionally or with the knowledge that such damage could probably have happened [7-10].

The Hamburg Rules (United Nations International Convention on the Carriage of Goods by Sea) in their Article 5 define that the carrier is liable for a delay in delivery if the occurrence, which caused the delay, took place while the goods were in their charge. Under the Hamburg Rules, the delay in delivery occurs when the goods have not been delivered at the port of discharge provided for in the contract of carriage by sea within the time expressly agreed upon or, in the absence of such an agreement, within the time, which it would be reasonable to require of a diligent carrier, having regard to the circumstances of the carriage. The liability of the carrier for a delay in delivery, according to provisions of Article 6 Paragraph 1, Subparagraph b) of the Hamburg Rules, is limited to an amount equivalent to two and a half times the freight payable for the goods delayed, but not exceeding the total freight payable under the contract of carriage of goods by sea. The aggregate liability of the carrier for damage of the freight and delay in delivery shall not exceed the amount, which would equal to the carrier's liability in the case of total loss of the freight. It is equivalent to two and a half times the units of account (SDR/XDR) per kilogram of gross weight, or 835 units of account per package or another freight/shipping unit. By agreement between the carrier and the consignor, limits of liability exceeding those quoted in the Hamburg Rules may be fixed [9, 28].

The Rotterdam Rules (United Nations Convention on Contracts for the International Carriage of Goods (Wholly or Partly) by Sea) [10] in their Article 21 define a delay as a moment when the freight is not delivered to the place of destination within the time expressly agreed upon. Under Article 60 of the Rotterdam Rules, the indemnity for loss or damage of the freight, due to a delay in delivery, is limited to an amount equivalent to two and a half times the freight payable for the goods lost or damaged. However, the full amount of indemnity must not exceed the amount, which would be payable in the case of total loss of freight. The carrier may ask for limitation of the liability in the case of intentional damages and negligence [29].

\section{Discussion}

The paper contains a thorough analysis of the law on the subject written primarily from the perspective of English law, but with reference to cases in other major developed countries. The main output focuses on international carriage measures, such as the Hague, Hague-Visby, Hamburg and Rotterdam Rules, the CMR, the COTIF/CIM, the Warsaw Convention and Montreal Protocol, CMNI and discusses the current developments towards uniformity. There are analysis of shippers' obligations, the obligations of the carrier and the rights and immunities of the carrier and there is a full coverage of the main issues in charterparties: transportation (including problems of Delivery time, delay in delivery). This paper seeks to examine, in a commercial context, the legal problems facing shipowners, charterers, shippers and receivers of goods and the solutions adopted by the courts and international conferences to those problems. Many of the legal principles involved are not restricted to shipping but serve the wider area of commercial law generally. The analysis shows that international rules present similarities in certain fields of international transport, however considerable differences exist (as each treaty was signed decades after the other) and to this respect the most important rules were compared with respect to the contract of carriage by the method of comparison. The dissimilarity of legislation is also shown and suggestions for further research in this area are given.

All the transport conventions contain a limitation of the compensation to be paid by a carrier. The Visby rules established the limitation per package at 666. 67 SDR, or 2 SDR per $\mathrm{kg}$. The Hamburg rules raised the limit to 835 SDR per package or 2.5 SDR per kg. The 1980 Multimodal Convention (that has not entered into force yet) raised limit to 920 SDR per package and 2.75 per kg. The Rotterdam Rules in Article 59 adopt the limit of 875 SDR per package or unit and 3 SDR per $\mathrm{kg}$. While the weight limits are still below those found in other modes, whether these new limits of liability are seen as better for cargo interests is, of course a different matter and will be evaluated by each cargo owner based on his or her claims history and experience. With comparison to unimodal modes, for instance the Budapest Convention on the Contract for the Carriage of Goods by Inland Waterway (CMNI) of 2001, establishing the liability of the carrier rate of 2 SDR per kilogram shipment or 666.67 SDR per package or any other unit load, or 1.500 SDR per container without the stored goods and further 25,000 SDR for goods stored in a container. The limit for transport of goods by air is almost nine times higher than the limit for maritime conveyances. However, the goods transported by air usually have a much higher value than their counterparts that are being shipped by sea [7-10]. Comparable Limits of Liability under Unimodal and Multimodal Regimes [20, 22-25] can be found in Table 1.

Containerization, the increasing complexity of modern supply chains, development of electronic documentation and the enhanced importance of security, have made carrier - shipper relations incredibly complex, while at the same time its driving governments towards a desire to harmonize the way in which global financial and trading rules are implemented. It is extremely important to the economic interests of all the 
Table 1 Comparable Limits of Liability under Unimodal and Multimodal Regimes

\begin{tabular}{|c|c|c|}
\hline regime & limit by weight & limit by item \\
\hline $\begin{array}{l}\text { sea carriage } \\
\text { - Hague rules (Arts. IV(5) and IX) } \\
\text { - Hague/Visby rules (Art. IV (5)) } \\
\text { - Hamburg rules (Art. 6) }\end{array}$ & $\begin{array}{c}\mathrm{n} / \mathrm{a} \\
2.00 \mathrm{SDR} / \mathrm{kg} \\
2.50 \mathrm{SDR} / \mathrm{kg}\end{array}$ & $\begin{array}{c}\text { U.S. } \$ 500 / \text { pkg }(=346.21 \mathrm{SDR} / \mathrm{pkg}) \\
666.67 \mathrm{SDR} / \mathrm{pkg} \\
835 \mathrm{SDR} / \mathrm{pkg},\end{array}$ \\
\hline ICC rules 1975 (rule $11(\mathrm{c})$ ) & $\begin{array}{l}30 \text { Poincare francs } / \mathrm{kg} \\
\quad(\sim 2 \mathrm{SDR} / \mathrm{kg})\end{array}$ & $\mathrm{n} / \mathrm{a}$ \\
\hline $\begin{array}{l}\text { multimodal convention } 1980 \text { (Art. 18(1), (3).) } \\
\text { - but if no sea leg }\end{array}$ & $\begin{array}{l}2.75 \mathrm{SDR} / \mathrm{kg} \\
8.33 \mathrm{SDR} / \mathrm{kg}\end{array}$ & $920 \mathrm{SDR} / \mathrm{pkg}$ \\
\hline $\begin{array}{l}\text { UNCTAD/ICC rules } 1992 \\
\text { (rules } 6.1 \text { and } 6.3 \text { ) } \\
\text { - but if no sea leg }\end{array}$ & $\begin{array}{l}2.00 \mathrm{SDR} / \mathrm{kg} \\
8.33 \mathrm{SDR} / \mathrm{kg}\end{array}$ & 666.67 SDR/pkg \\
\hline Rotterdam rules 2009 (Art. 59) & $3 \mathrm{SDR} / \mathrm{kg}$ & $875 \mathrm{SDR} / \mathrm{pkg}$ \\
\hline road carriage-CMR (Art. 23) & 8.33 SDR/kg & $\mathrm{n} / \mathrm{a}$ \\
\hline $\begin{array}{l}\text { rail carriage-CIM uniform rules } \\
\text { (Arts. } 7,40 \text { and } 42 \text { ) }\end{array}$ & $17.00 \mathrm{SDR} / \mathrm{kg}$ & $\mathrm{n} / \mathrm{a}$ \\
\hline $\begin{array}{l}\text { air carriage-Warsaw convention/ Montreal convention } \\
\text { (Art. } 22(2) \text { ) }\end{array}$ & $17.00 \mathrm{SDR} / \mathrm{kg}$ & $\mathrm{n} / \mathrm{a}$ \\
\hline inland water carriage - CMNI (Art. 20) & $2 \mathrm{SDR} / \mathrm{kg}$ & $\begin{array}{c}\text { 666.67 SDR/pkg, } \\
1500+25000 \mathrm{SDR} / \text { container }\end{array}$ \\
\hline
\end{tabular}

n/a (not available)

SDR (Special Drawing Rights)

trading nations that complicated supply chain functions seamlessly and equitably for all involved. To achieve such a goal, there must be not only the political will to sign and ratify improvements on existing carriage rules, but the widespread adoption of the contract terms as well, without exemptions being negotiated at the firm contract negotiation level.

The idea of the Rotterdam Rules is that it shall apply door-to-door mode, regardless of the mode of transport, as long as an international sea leg is involved. This broad scope of application of the Rotterdam Rules carries a risk of conflicts with unimodal transport conventions, which regulates carriage by air, road carriage, carriage by rail and carriage by inland water. Moreover, as the Rotterdam Rules only apply in the cases where damage is attributable to the marine sea leg, they are still not attractive from a cargo perspective, even though they have been more explicit in defining delay and have raised the limits of liability. For multimodal transport, there remains considerable confusion as to what will work best in the door-to door context and a trading environment focused on timebased competition where the consequences of cargo delay are a paramount consideration for a large portion of the moves [29-30].

\section{Conclusion}

The delivery time is usually negotiated in the contract of carriage between individual contracting parties, or it results from respective regulations or international treaties. European courts (mostly those of higher instances) have practiced appropriate periods of carriage (carriage times) several times, e.g. between Germany and Greece, Germany and Turkey, but these periods cannot be considered binding and applicable in all the cases.

The diversity of regulations in the area of international carriage of consignments through individual transport modes, mainly in context of the multimodality development, brings inconsistency and disharmony to the transport market. In conjunction with the anticipated and supported development of multimodal transport and a wider engagement in intermodal transport chains, the authors do recommend the unification of transport-legal conditions, not only with regard to delivery times in international carriage of goods and sanctions resulting from delay in delivery.

\section{Acknowledgement}

This work was supported by Project VEGA No. 1/0128/20: Research on the Economic Efficiency of Variant Transport Modes in the Car Transport in the Slovak Republic with Emphasis on Sustainability and Environmental Impact, Faculty of Operation and Economics of Transport and Communications: University of Zilina, 2020-2022. 


\section{References}

[1] CULIK, K., KALASOVA, A., KUBIKOVA, S. Smart city - model of sustainable development of cities. In: 11th International Science-Technical Conference Automotive Safety: proceedings. 2018. p. 5.

[2] Traffic law e-newsletter [online]. 2007-2019. Available from: http://akmsv.cz/e-bulletin.

[3] FAGHFOURI, M. Overview of the UNCITRAL draft convention on contracts for the international carriage of goods wholly or partly by sea - IMMTA-News [online]. 2008. Available from: http://www.immta.org/uploads/ IMMTANews-2008-1.pdf

[4] PAULAUSKAS, V., BENTZEN, K. Sea motorways as a part of the logistics chain. Transport [online]. 2008, 23(3), p. 202-207. ISSN 1648-4142, eISSN 1648-3480. Available from: https://doi.org/10.3846/1648-4142.2008.23.202207

[5] LINGAITIENE, O. A mathematical model of selecting transport facilities for multimodal freight transportation. Transport [online]. 2008, 23(1), p. 10-15. ISSN 1648-4142, eISSN 1648-3480. Available from: https://doi.org/10.3846/1648-4142.2008.23.10-15.

[6] AFANDIZADEH, S., MOAYEDFAR, R. The feasibility study on creation of freight village in Hormozgan province. Transport [online]. 2008, 23(2), p. 167-171. ISSN 1648-4142, eISSN 1648-3480. Available from: https://doi.org/10.3846/1648-4142.2008.23.167-171.

[7] Hague rules. International convention for the unification of certain rules of law relating to bills of lading.

[8] Hague-Visby rules. Protocol to amend the international convention for the unification of certain rules of law relating to bills of lading.

[9] Hamburg rules. United Nations international convention on the carriage of goods by sea.

[10] Rotterdam rules. United Nations convention on contracts for the international carriage of goods (wholly or partly) by sea.

[11] TOLLI, A., LAVING, J. Container transport direct call - Logistic solution to container transport via Estonia. Transport [online]. 2007, 22(4), p. Ia-If. ISSN 1648-4142, eISSN 1648-3480. Available from: https://doi.org/10.10 80/16484142.2007.9638149

[12] JARZEMSKIENE, I. The evolution of intermodal transport research and its development issues. Transport [online]. 2007, 22(4), p. 296-306. ISSN 1648-4142, eISSN 1648-3480. Available from: https://doi.org/10.3846/164 84142.2007.9638145

[13] VASILIAUSKAS, A. V., BARYSIENE, J. An economic evaluation model of the logistic system based on container transportation. Transport [online]. 2008, p. 23(4), p. 311-315. ISSN 1648-4142, eISSN 1648-3480. Available from: https://doi.org/10.3846/1648-4142.2008.23.311-315

[14] JARZEMSKIENE, I., JARZEMSKIS, V. Allotment booking in intermodal transport. Transport [online]. 2009, 24(1), p. 37-41. ISSN 1648-4142, eISSN 1648-3480. Available from: https://doi.org/10.3846/1648-4142.2009.24.3741

[15] LIU, W., XU, H., ZHAO, X. Agile service oriented shipping companies in the container terminal. Transport [online]. 2009, 24(2), p. 143-153. ISSN 1648-4142, eISSN 1648-3480. Available from: https://doi.org/10.3846/16484142.2009.24.143-153

[16] TETLEY, W. Reform of carriage of goods - the uncitral draft and Senate COGSA'99. Tulane Maritime Law Journal. 2003, 28(1), p. 1-44. ISSN 1048-3748.

[17] BURKOVSKIS, R. Efficiency of freight forwarder's participation in the process of transportation. Transport [online]. 2008, 23(3), p. 208-213. ISSN 1648-4142, eISSN 1648-3480. Available from: https://doi.org/10.3846/16484142.2008.23.208-213

[18] LINGAITIENE, O. A mathematical model of selecting transport facilities for multimodal freight transportation. Transport [online]. 2008, 23(1), p. 10-15. ISSN 1648-4142, eISSN 1648-3480. Available from: https://doi.org/10.3846/1648-4142.2008.23.10-15

[19] JARZEMSKIS, A., VASILIAUSKAS, A. V. Research on dry port concept as intermodal node. Transport [online]. 2007, 22(3), p. 207-213. ISSN 1648-4142, eISSN 1648-3480. Available from: https://doi.org/10.3846/16484142.200 7.9638126

[20] CMR. Convention on the contract for the international carriage of goods by road.

[21] CULIK, K., KALASOVA, A., KUBIKOVA, S. Simulation as an instrument for research of driver-vehicle interaction. MATEC Web of Conferences [online]. 2017, 134, 00008. eISSN 2261-236X. Available from: https://doi.org/10.1051/matecconf/201713400008

[22] COTIF. Convention concerning international carriage by rail.

[23] Warsaw convention. Convention for the unification of certain rules relating to international carriage by air.

[24] Montreal convention. Convention for the unification of certain rules for international carriage by air.

[25] CMNI. Budapest convention on the contract for the carriage of goods by inland Waterways. 
[26] JURKOVIC, M., DAVID, A. Technological and educational requirements for inland navigation simulator in the Danube region. Nase More / Our Sea [online]. 2015, 62(1), p. 13-19. ISSN 0469-6255, e-ISSN 1848-6320. Available from: https://doi.org/10.17818/NM.1.3.2015

[27] International maritime conventions. Prague: Czechoslovak Chamber of Commerce and Industry, 1981.

[28] JAGELCAK, A., DAVID, A. Maritime transport and maritime containers. Bytca: Druska Books as university textbook. 2014. ISBN 978- 80- 89646- 90-6.

[29] GROBARCIKOVA, A., SOSEDOVA, J. Carrier's liability under the international conventions for the carriage of goods by sea. Transport Problems / Problemy Transportu. 2014, 9(3), p. 75-82. ISSN 1896-0596, eISSN 2300$861 X$.

[30] SPARKA, F. Jurisdiction and arbitration clauses in maritime transport documents. Berlin: Springer-Verlag, 2010. ISSN 1614-2462. 